\title{
Ecological Study of Grey Heron in Oga Peninsula, Akita Prefecture
}

\author{
Ko Ogasawara*, Kaname Abe** and Toshihiko Naito***
}

\begin{abstract}
Located at about $30 \mathrm{~km}$ north-west of Akita City, a colony of the Grey Heron (Ardea cinerea) has been maintained at the foot of Mt. Honzan in Oga Peninsula. It is surrounded by a natural 24.8 ha cedar (Criptomeria japonica) forest of about 215 trees, approximately 150 years old. We made a distribution map of cedar trees and marked every tree, and their nest sites were indicated. The population size of Grey Herons in this colony was estimated to be about 390 in 1980 and 400 in 1981. All-day observations were done to investigate their feeding behavior. Departure and return to and from the colony were frequent both in the morning and the evening. The dropped foods, dead-nestlings and adult birds were eaten by mice and unknown middle-sized mammals, and decomposed by many insects. The Grey Heron colony has existed very long time, and big old cedar trees are gradually dying year by year. As the result, the whole colony is forced to move toward the north of the forest.
\end{abstract}

\section{Introduction}

The Grey Heron breeds in Hokkaido, Honshu and Shikoku etc. They nest in colony on woods of large trees and forage on rice paddies, marshes and other wetlands. They have a habit to use the same nest year to year.

There are two colonies in Akita Prefecture. The one, only recently (1980) found by Izumi in Omonogawa-Machi(personal communication), is a colony formed on planted cedar trees mixed with Night Herons (Nycticorax n. nycticorax). The other one is in Oga Peninsula, and is known since as old as at least WWII. Majority of the Grey Herons in Akita leaves in winter to warmer district, but a few of them remain in Akita Pref., especially in warmer winter.

Some observations at Oga Peninsula colony have been made by Usuta (personal communication), Hashimoto \& Ogasawara (1968), and Ogawa (1979). Here we report our recent survey.

\section{Study Area}

The colony of Grey Heron in Oga Peninsula is at the foot of Mt. Honzan ( $715 \mathrm{~m}$ alt.), about $30 \mathrm{~km}$ north-west of Akita City, at an elevation of about $400 \mathrm{~m}$ (Fig. 1). It breeds in a part of 24.8 ha indigenous cedar (Criptomeria japonica) forest, consisting of about 215 trees, estimated to be approximately 150 years old in average. This natural forest is surrounded by planted cedars and has a narrow valley and there is a small

* Department of Biology, Education, Akita University, Tegata Gakuencho, Akita 010, Japan.

** Hirasawa Primary School of Nikaho-Machi, Akita 010, Japan.

*** Botanical Garden of Tohoku University, Kawauchi, Sendai 980, Japan. 


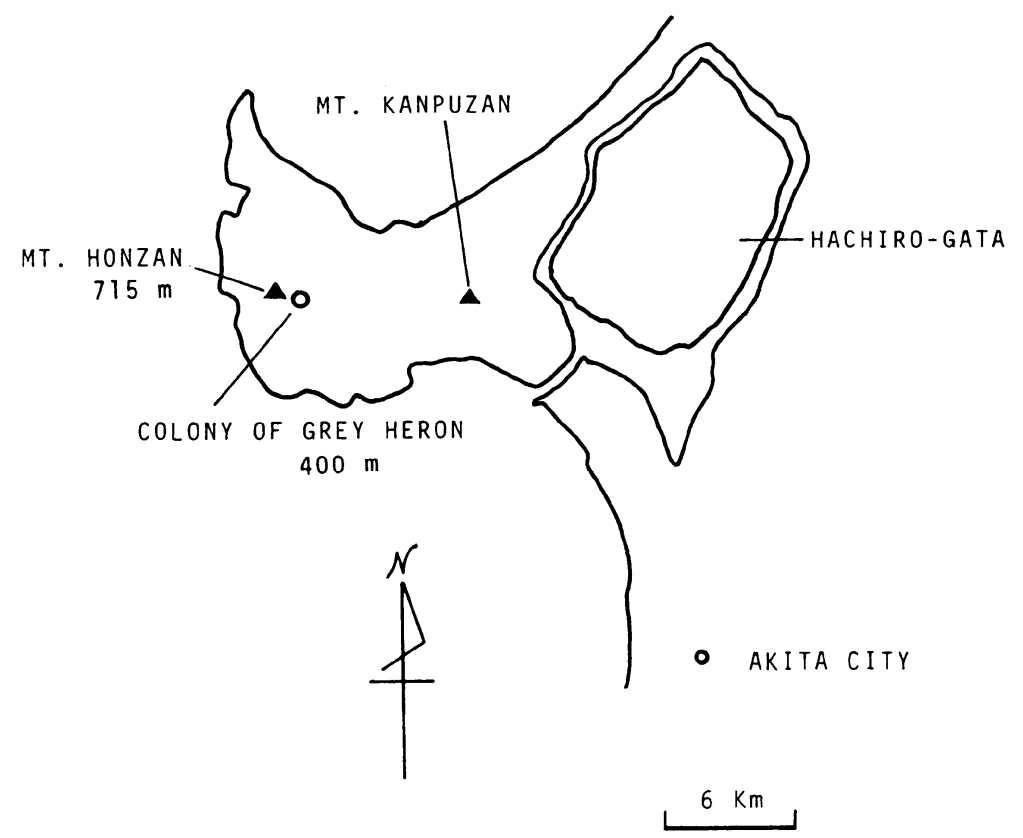

Fig. 1. Map of Oga Peninsula and the place of Grey Heron's colony surveyed.

stream at its northern part. A road leading to the top of Mt. Honzan passes near the west side of the forest (Figs. 1, 2). In 1967, this Mt. Honzan colony was designated as a Prefectural Natural Monument, because it was then the only known heron colony in Akita Prefecture.

Grey Herons usually breed in company with other heron species, as in Nagaoka-shi (Watanabe 1976) and above mentioned Omonogawa-machi colonies. However, at Mt. Honzan, the Grey Herons form a single-species colony. This forest has been kept stable as a natural cedar forest, although Grey Herons have affected it to some extent. Small number of Magnoria obovata, Aesculus turbinata and Morus bombycis etc. are mixed among dominant cedar trees. Rich shrub and herb strata grow on rather moist forest floor.

\section{Methods of Investigations}

Investigations at breeding and feeding areas were executed from June to December 1980 and 1981.

Distribution map of cedar trees was made by marking directions, and elevation and measuring distances of every trees with measure and clinometer. Height of every one tree was determined by the following method; first, one tree was selected and its height was determined by triangulation. Then, heights of surrounding trees were determined one by one by comparing with the first tree. Every tree was classified into four types according to degree of defection of branches. Type A stands for trees whose canopy is 


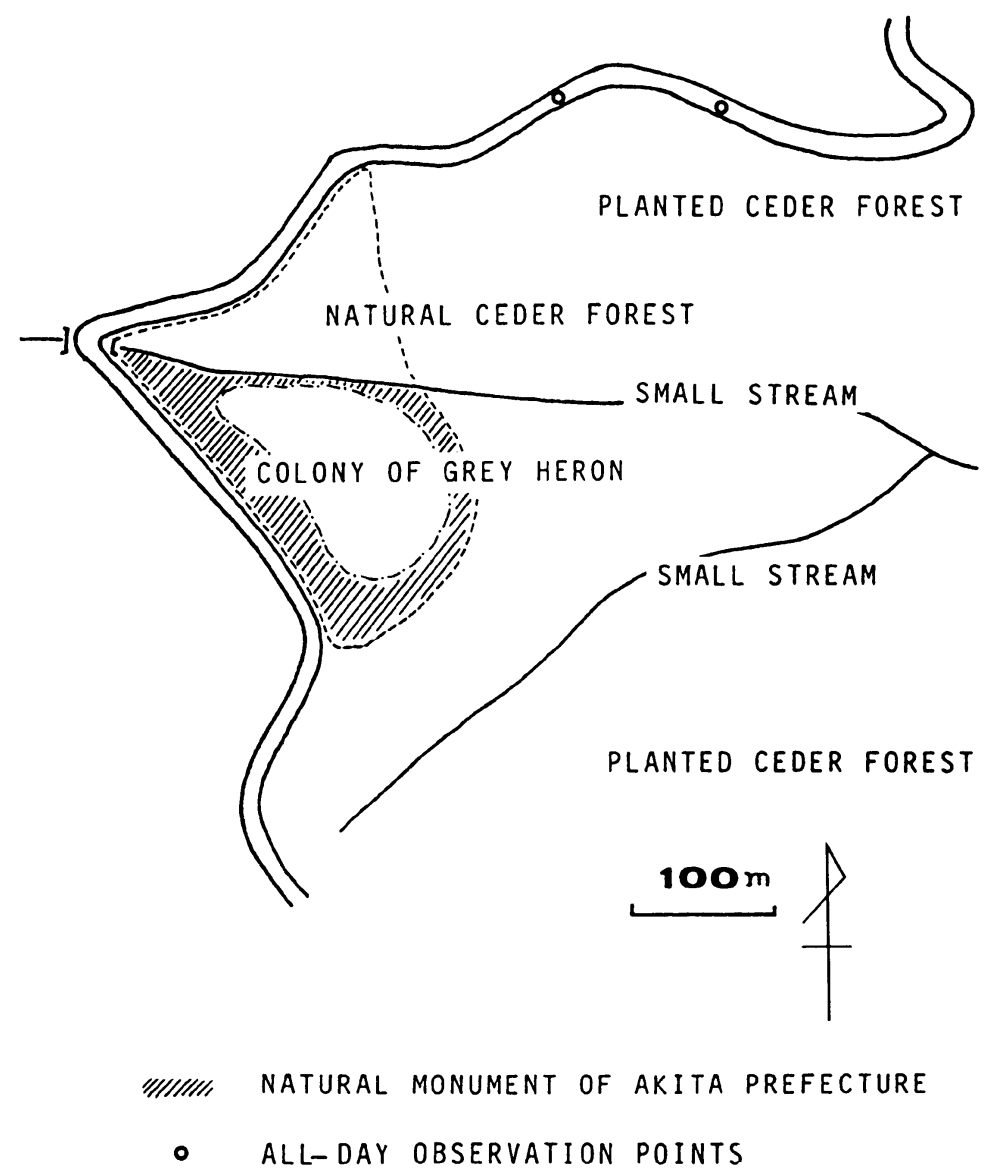

Fig. 2. Map of the colony of Grey Heron and its sorroundings.

well covered with branches and leaves, the canopy being invisible from the foot of the tree. Type B stands for ones whose canopy is slightly visible. Type C stands for ones whose canopy is completely exposed of dead branches, and Type D stands for completely died out wood.

To conjecture Grey Herons' damage on vegetation, three quadrats were located; one was selected at another natural cedar forest of higher altitude on Mt. Honzan, and others were selected in this forest.

Number of birds was counted by binoculars from two points on the road (Fig. 2), which has about $200-300 \mathrm{~m}$ north-east from the colony. The position and number of nests, and the number of nestlings on each nest were counted from under the trees, or looked down from the top of the slope. On 11 July 1980, dozens of dropped nestlings and some adults were found, and various animals which lived depending upon the bodies of the dropped birds were recorded. We investigated the roles of these animals as decomposers of bird bodies, heron's excrete or pellets, by using bait-traps and mouse- 
traps.

\section{Results}

\section{Colony environments}

Fig. 3 shows distribution map of cedar trees in this natural forest. This forest had in total 215 cedar trees. Dead cedars were $19(8.6 \%)$ and half-dead trees were $6(2.7 \%)$, so that number of dead and half-dead cedars which seemed to be affected by Grey Herons was $11.3 \%$ of the total cedars. In respect of tree-height, the old and big trees of 35 to

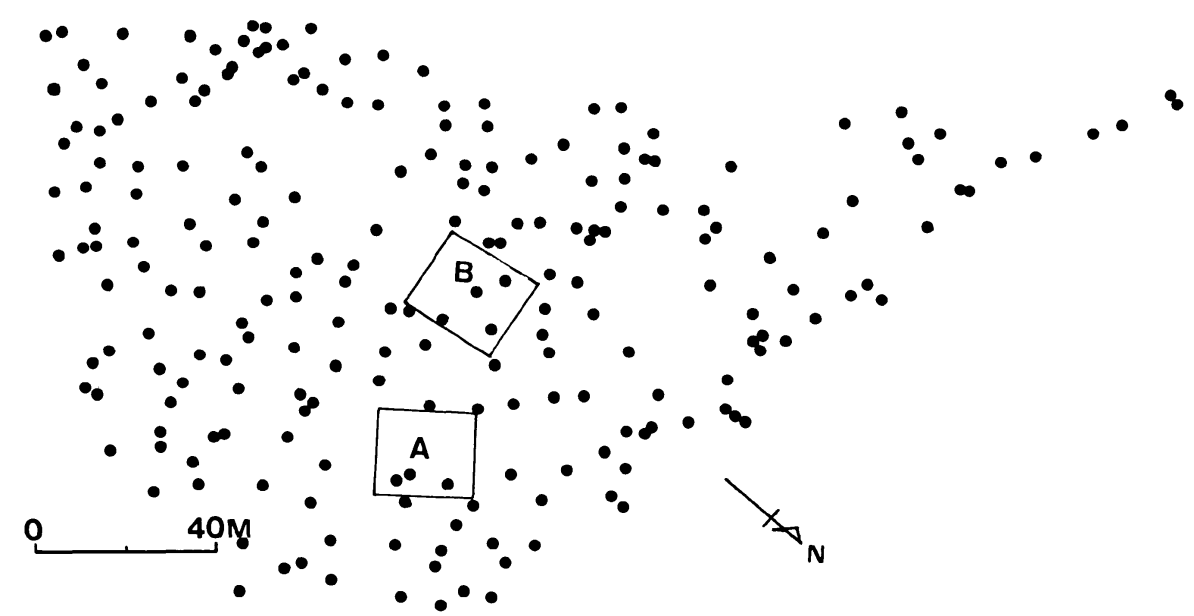

Fig. 3. Distribution map of natural cedar trees sorrounding the colony of Grey Heron. A and $B$ show the quadrates in which vegetational analysis was done.
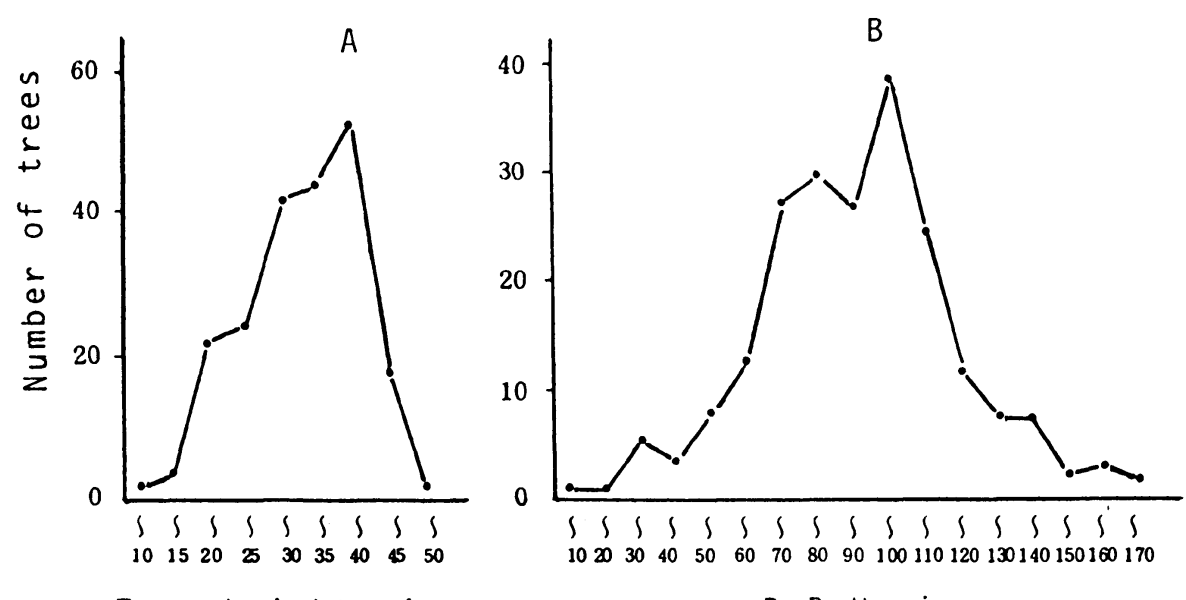

Tree heights in $\mathrm{m}$.

$$
\text { D.B.H. in } \mathrm{cm}
$$

Fig. 4. A; the relationship between number of trees and tree heights. B; the relationship between number of trees and D.B.H. 


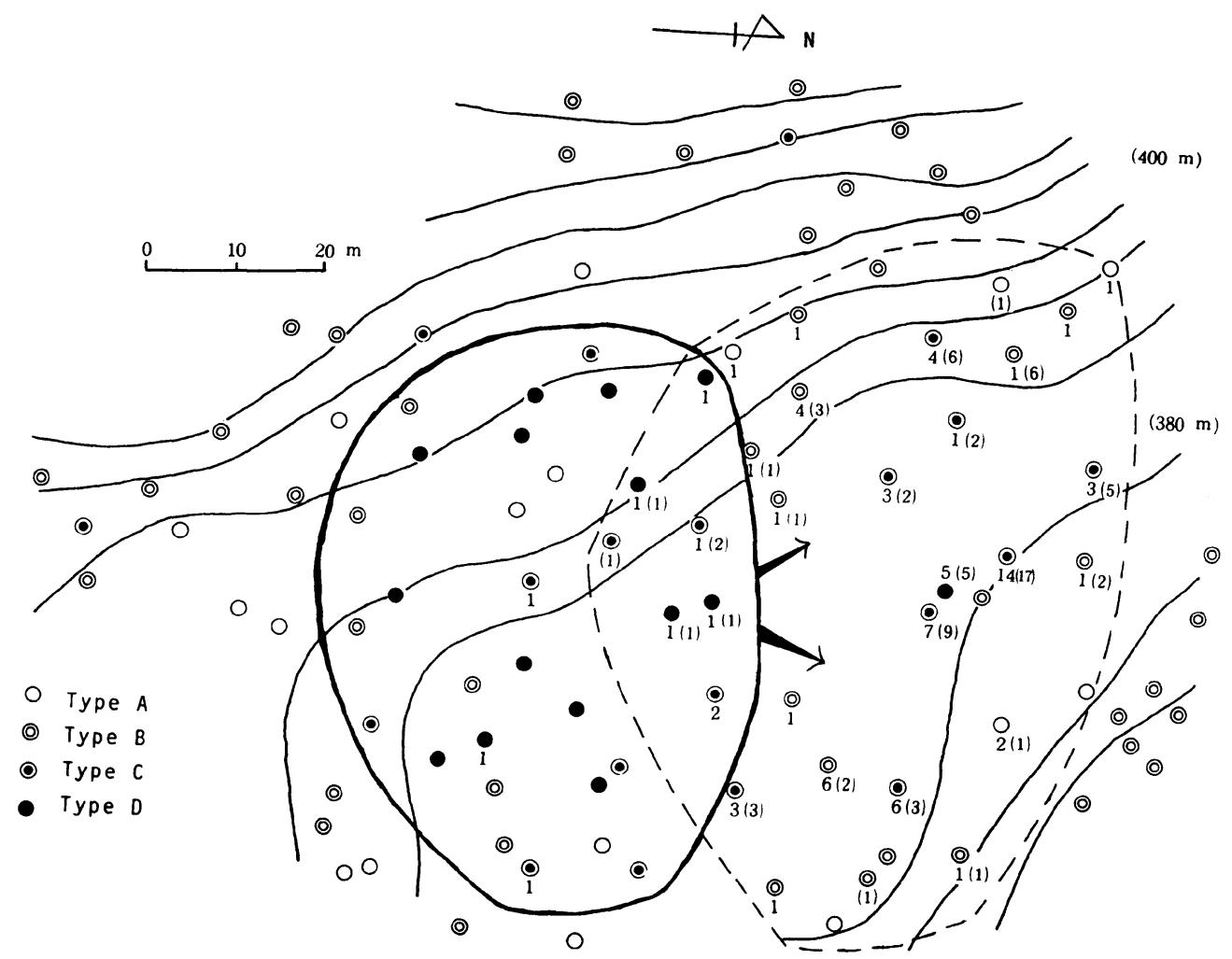

Fig. 5. Distribution map of cedar trees in the colony represented by tree types A-D (see text). Numerals show number of nest on each tree in 1981 .

Numerals in brackets show number of nest in 1980.

$40 \mathrm{~m}$ were most numerous and trees less than $10 \mathrm{~m}$ were quite rare (Fig. 4A). Fig. 4B shows propotion of D.B.H., in which the average range of D.B.H. was on $90-100 \mathrm{~cm}$ and maximum was $162 \mathrm{~cm}$.

Fig. 5 shows a distribution map of cedar trees which contained heron nests. Every tree is classified into four types according to the forementioned category. Type C and D were found gathered in the center of this colony, surrounded by type A and B. Though there were some type A cedars in the area where type C and D were dominant, these trees were about only $25 \mathrm{~m}$ in height, and therefore have not been used by Grey Herons yet.

\section{Favorite trees and nesting positions for Grey Herons}

Table 1 shows average heights and D.B.H. of nested and non-nested trees in this study area. Nested trees were more than about $5 \mathrm{~m}$ taller than non-nested trees in average, and similar tendency also could be seen in D.B.H. It is obvious that Grey Herons choose relatively larger trees. In the case of Omonogawa-machi, they preferably nested on trees $3 \mathrm{~m}$ taller than surrounding trees (Abe; personal communication). These 
facts seem to mean that they choose nesting trees by their heights rather than D.B.H.

In Table 2, number of nested trees in each tree-types, and at the same time, number of nests on each tree are shown. In all, number of nested trees was 24, type C and B trees were dominant $(C+B=75 \%)$ and they were much more than the sum of types $A$ and $D$. Grey Herons made highest number of nests per one tree in type C, thus, 17 and 14 nests were found in one tree of this type in 1980 and 1981 respectively. One tree of the type D had 5 nests, because enough branches still remained on it. In 1981, the same tendency is

Table 1. Relation between average tree height and DBH of every tree, nesting tree and nonnesting tree, in the present study area.

\begin{tabular}{lcc}
\hline \hline \multicolumn{1}{c}{ Ceder trees } & Tree height $(\mathrm{m})$ & DBH of ceder trees $(\mathrm{cm})$ \\
\hline Every tree & 34.5 & 90.5 \\
Nesting trees & 38.6 & 101.5 \\
Non-nesting trees & 33.3 & 87.1 \\
\hline
\end{tabular}

Table 2. Number of nests in four categories of types of nesting trees (1980). Numeral in branket shows number of nests.

\begin{tabular}{|c|c|c|c|c|c|c|c|c|c|c|c|c|c|c|}
\hline \multirow{2}{*}{$\begin{array}{c}\text { Types of nesting } \\
\text { trees }\end{array}$} & \multicolumn{10}{|c|}{ Number of nests } & \multirow{2}{*}{$\begin{array}{c}\text { Total number } \\
\text { of trees }\end{array}$} & \multirow{2}{*}{$\%$} & \multirow{2}{*}{$\begin{array}{l}\text { Total number } \\
\text { of nests }\end{array}$} & \multirow{2}{*}{$\%$} \\
\hline & 1 & 2 & 3 & 4 & 5 & 6 & 7 & 8 & 9 & 10 & & & & \\
\hline A & 2 & & & & & & & & & & 2 & 8.3 & 2 & 2.6 \\
\hline B & 4 & 2 & 1 & & & 1 & & & & & 8 & 33.3 & 17 & 22.1 \\
\hline $\mathrm{C}$ & 1 & 3 & 2 & & 1 & 1 & & & 1 & $\begin{array}{c}1 \\
(17)\end{array}$ & 10 & 41.7 & 50 & 64.9 \\
\hline D & 3 & & & & 1 & & & & & & 4 & 16.7 & 8 & 10.4 \\
\hline $\begin{array}{l}\text { Number of } \\
\text { nesting trees }\end{array}$ & 10 & 5 & 3 & & 2 & 2 & & & 1 & 1 & 24 & & & \\
\hline $\begin{array}{l}\text { Total number } \\
\text { of nests }\end{array}$ & 10 & 10 & 9 & & 10 & 12 & & & 9 & 17 & & & 77 & \\
\hline
\end{tabular}

Table 3. Number of nests in four categories of types of nesting trees (1981). Numeral in branket shows the number of nests.

\begin{tabular}{|c|c|c|c|c|c|c|c|c|c|c|c|c|c|}
\hline \multirow{2}{*}{$\begin{array}{c}\text { Types of } \\
\text { nesting trees }\end{array}$} & \multicolumn{9}{|c|}{ Number of nests } & \multirow{2}{*}{$\begin{array}{c}\text { Total number } \\
\text { of trees }\end{array}$} & \multirow{2}{*}{$\%$} & \multirow{2}{*}{$\begin{array}{c}\text { Total number } \\
\text { of nests }\end{array}$} & \multirow{2}{*}{$\%$} \\
\hline & 1 & 2 & 3 & 4 & 5 & 6 & 7 & 8 & $9<$ & & & & \\
\hline A & 2 & 1 & & & & & & & & 3 & 9.4 & 4 & 5.1 \\
\hline B & 9 & & & 1 & & 1 & & & & 11 & 34.4 & 19 & 24.1 \\
\hline $\mathrm{C}$ & 5 & 1 & 3 & 1 & & 1 & 1 & & $\begin{array}{c}1 \\
(14)\end{array}$ & 13 & 40.6 & 47 & 59.5 \\
\hline $\mathrm{D}$ & 4 & & & & 1 & & & & & 5 & 15.6 & 9 & 11.4 \\
\hline $\begin{array}{l}\text { Number of } \\
\text { nesting trees }\end{array}$ & 20 & 2 & 3 & 2 & 1 & 2 & 1 & & 1 & 32 & & & \\
\hline Number of nests & 20 & 4 & 9 & 8 & 5 & 12 & 7 & & 14 & & & 79 & \\
\hline
\end{tabular}


Table 4. Number of nests and its percentages in types of nesting trees and nesting parts of trees in 1980 .

\begin{tabular}{|c|c|c|c|c|c|}
\hline \multirow[b]{2}{*}{$\begin{array}{c}\text { Types of } \\
\text { nesting trees }\end{array}$} & \multicolumn{5}{|c|}{ Types of nesting parts } \\
\hline & $\begin{array}{c}\mathrm{X} \\
\text { Top of tree }\end{array}$ & $\begin{array}{l}\mathrm{Y} \\
\text { Forked part of the } \\
\text { trunk and bough }\end{array}$ & $\begin{array}{c}\mathrm{Z} \\
\begin{array}{c}\text { Forked part of } \\
\text { branches }\end{array}\end{array}$ & $\begin{array}{c}\text { Number of } \\
\text { nests }\end{array}$ & $\%$ \\
\hline A & 2 & & & 2 & 2.6 \\
\hline B & 8 & 3 & 6 & 17 & 22.1 \\
\hline $\mathrm{C}$ & 9 & 8 & 33 & 50 & 64.9 \\
\hline $\mathrm{D}$ & 4 & 2 & 2 & 8 & 10.4 \\
\hline $\begin{array}{l}\text { Total number of } \\
\text { nests }\end{array}$ & 23 & 13 & 41 & 77 & \\
\hline$\%$ & 29.9 & 16.9 & 53.2 & & \\
\hline
\end{tabular}

recognized as shown in Table 3.

In considering the relationship between tree-type and number of nests, observer should be positioned and count the nest at the foot of each tree. Counting of nests on type $\mathrm{C}$ and $\mathrm{D}$ trees is very easy, because nests are always exposed. However, in types $\mathrm{A}$ and $\mathrm{B}$, nests are often hidden among branches and leaves. Therefore, in spite of three times counting, there will be some nests missed. Total number of nests thus counted from the root of each tree was 77 in 1980, and 79 in 1981. On the other hand, the number of nests from two points along the road was 109 in 1980, and 105 in 1981.

The nesting position could be classified into three types; type $\mathrm{X}$ stands for nest on the top of trunk, type $\mathrm{Y}$ stands for nest between trunk and bough, and type $\mathrm{Z}$ stands for nest on the end of bough. Table 4 shows correlation of types of tree and types of nesting position. Type $\mathrm{C}$ trees had many nests (50 nests, about $65 \%$ ) and also had the highest average number of nests per one tree. Type $\mathrm{Z}$ nests were the most common in relation to nesting position $(41,53 \%)$ and they were found most commonly on type $C$ trees. The second common type of nest site was type $\mathrm{X}$, which was observed on every nested tree, so that it seems to be the most preferred nesting position for Grey Heron.

These facts may suggest the following relations between tree types and nesting preference of Grey Herons. First they prefer to nest on the top of tree trunk, then their frequent perch and excrete may cause the dying of affected branches. Other pairs may build their nests on non-affected branches under the dying branch. Nests would increase in such a way and would accelerate dying of more branches. Finally, the tree would die, and suitable position of nesting would remain only on top of the tree. Through such a process, tree type seems to proceed from A to D. Type C trees have much more space for nesting than other types. The colonial habit of the Grey Heron to nest on the same site through years would be an additional factor for the tree-type changing process.

\section{Influence of heron colony to vegetation}

In previous studies, vegetational counts of cedar trees were only made of nested trees, the total numbers have been reported as follows; 28 trees in 1968 (Hashimoto \& 
Ogasawara) and $30+$ in 1979 (Ogawa). The fate of nesting trees had only been noticed by Ogawa (1979), who thought that every cedar trees begin to die when it is nested by Grey Heron. When a cedar become completely dead, almost all its branches have been lost and Grey Herons lose their nesting site, and are forced to move to other trees.

Fig. 5 shows such a process of nest site replacement. The area where type $D$ trees are concentrated is circled by broken line. No nest was observed north of a narrow valley until the previous year, but two nests were newly found, suggesting the northward shift of the colony. In the eastern part of this natural forest where a road passes nearby, no nest nor visit of Grey Heron was noticed, although there were many large cedars. This reflects very alert nature of the Grey Heron. Therefore, this colony will continue to extend to north in future.

Grey Hersons are also influential to herb stratum. Death of branches locally increases light penetration, and various herb-species which usually occur in the depth of forest or along lowland water course were found on the forest floor of the colony. Probably, seeds of these plants should have been carried by Grey Herons from their feeding grounds, and indirectly by other animals (rodents) ingested by Grey Herons. Vegetation change is thus steadily progressing and such area is extending.

\section{Trends of heron population}

The count of the number of Grey Herons of the colony was not easy, because many

Table 5. Average brood-sizes of Grey Heron in 1980 and 1981.

\begin{tabular}{|c|c|c|c|c|c|c|c|}
\hline Dates of observations & & $1^{*}$ & $2^{*}$ & $3^{*}$ & $4^{*}$ & Total & Average brood-size \\
\hline \multirow[t]{2}{*}{7 June 1980} & Number of nests & 3 & 10 & 5 & 1 & 19 & \multirow{2}{*}{2.05} \\
\hline & Number of nestlings & 3 & 20 & 15 & 4 & 39 & \\
\hline \multirow[t]{2}{*}{21 June 1980} & Number of nests & 9 & 24 & 4 & 0 & 37 & \multirow{2}{*}{1.86} \\
\hline & Number of nestlings & 9 & 48 & 12 & 0 & 69 & \\
\hline \multirow[t]{2}{*}{7 July 1980} & Number of nests & 7 & 12 & 3 & 0 & 22 & \multirow{2}{*}{1.80} \\
\hline & Number of nestlings & 7 & 24 & 9 & 0 & 40 & \\
\hline \multirow[t]{2}{*}{16 June 1981} & Number of nests & 24 & 22 & 13 & 0 & 59 & \multirow{2}{*}{1.80} \\
\hline & Number of nestlings & 24 & 44 & 39 & 0 & 107 & \\
\hline
\end{tabular}

* Number of nestlings per one nest.

Table 6. Estimated population sizes of Grey Heron during 1955 to 1981.

\begin{tabular}{|c|c|c|c|c|c|}
\hline Years & $\begin{array}{l}\text { Total number } \\
\text { of birds }\end{array}$ & $\begin{array}{c}\text { Number of } \\
\text { nests }\end{array}$ & $\begin{array}{c}\text { Number of } \\
\text { adults }\end{array}$ & $\begin{array}{c}\text { Number of } \\
\text { nestlings }\end{array}$ & Investigators \\
\hline 1955 & $1000 \pm$ & 1 & 1 & 1 & \multirow{6}{*}{$\begin{array}{c}\text { Usuta } \\
\text { Usuta } \\
\text { Hashimoto } \\
\text { \& Ogasawara } \\
\text { Ogawa }\end{array}$} \\
\hline 1963 & $280 \pm$ & 71 & $140 \sim 150$ & $140 \pm$ & \\
\hline 1967 & $280 \pm$ & $80 \sim 90$ & $160 \pm$ & $120 \sim 150$ & \\
\hline $1975 \sim 1979$ & $400 \pm$ & $110 \sim 120$ & $200 \pm$ & $200 \pm$ & \\
\hline 1980 & $390 \pm$ & 109 & $220 \pm$ & $140 \sim 170$ & \\
\hline 1981 & $400 \pm$ & 105 & $210 \pm$ & $190 \pm$ & \\
\hline
\end{tabular}


are missed hidden by branches and leaves or being absent for feeding. So that we estimated total number of individuals from average brood-size according to the result from investigations on 7 June, 21 June and 17 July in 1980 and 16 June in 1981 (Table 5). Average brood-size plus 2 (pair) should be average number of birds per one nest.

Average brood-size was estimated to be at least 1.80 from the result of actual counts of nestlings of 22 nests in 1980 and 59 in 1981. In this estimation, some immatures fledged from these 22 and 59 nests before investigation, are not included, because Grey Heron begins incubation after first egg is laid, and therefore chicks fledge on different dates. The average brood-size decreased from 2.05 on 7 June, 1.86 on 21 June, and 1.80 on 17 July in 1980 and 1.80 on 16 June in 1981. The cause of this decrease seems to be by loss of nestlings that fall to the ground from the nest (Table 5).

Based on the above observations, we estimate the population size of Grey Herons in this colony to be about 390 in 1980 and 400 in 1981. These numbers are
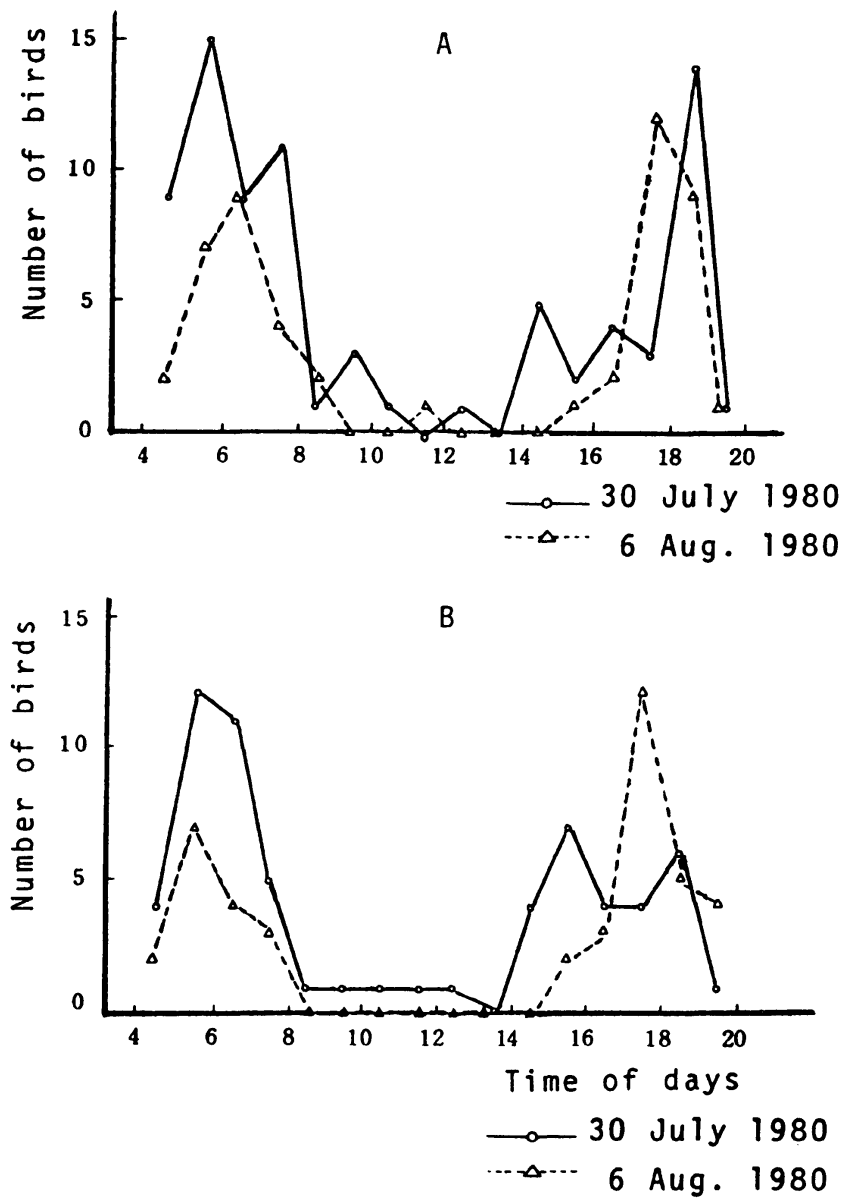

Fig. 6. The activities of departure for foraging (A), and of returning from foraging areas (B), by all-day observations in 1980 . 
approximately similar to Ogawa's data (1979), and the colonial population seems to be stable in recent years (Table 6).

\section{Feeding of nestlings}

All-day observations of the feeding of nestlings were made on 30 July, 6 August in 1980, and 23 May, 16 June in 1981. Fig. 6 (A, B) and Fig. 7 (A, B) show the rates and frequencies of foraging departure and return to the colony. These Figs. show that both departures and returns are frequent in the morning and in the evening. This cofirms our former observations. Table 7 shows correlation between number of nests and feeding frequency per one nest. The feeding frequencies of parents ranged between 2 and 4 per one day, and thrice per day were the commonest frequencies.

Judging from the frequency of departures and returns in the early morning, some of parent birds which came back early in the morning may have stayed over night at roosting sites in foraging area. The departure of some birds late in the evening from the colony supports this, and in fact, there are roosting places near the feeding area.
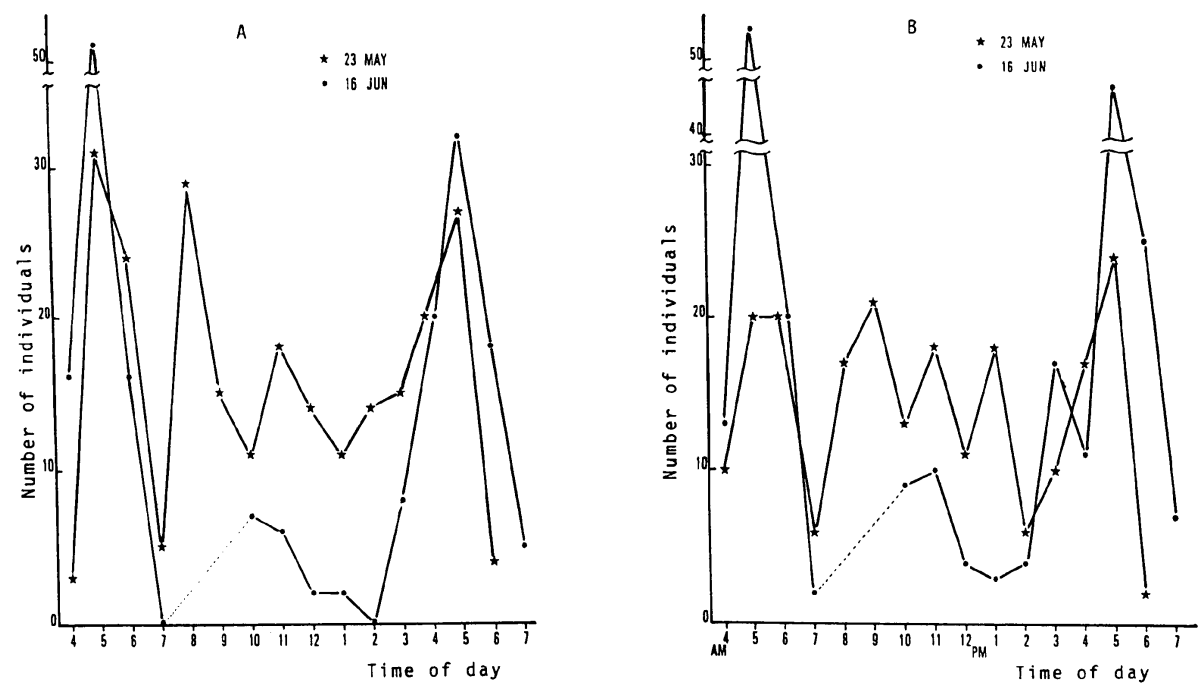

Fig. 7. The same of Fig. 6 in 1981.

Table 7. Number and its percentages of feedings for nestlings per day by all-day observations (1980).

\begin{tabular}{cccccccc}
\hline \hline \multirow{2}{*}{$\begin{array}{c}\text { Number of } \\
\text { feedings }\end{array}$} & \multicolumn{2}{c}{30 July } & & \multicolumn{2}{c}{6 Aug. } & & Total number \\
& No. of nests & $\%$ & & No. of nests & $\%$ & & $\%$ \\
\hline 2 & 4 & 36.4 & 2 & 20.0 & 6 & 28.6 \\
3 & 6 & 54.6 & 6 & 60.0 & 12 & 57.1 \\
4 & 1 & 9.0 & 2 & 20.0 & 3 & 14.3 \\
\hline
\end{tabular}




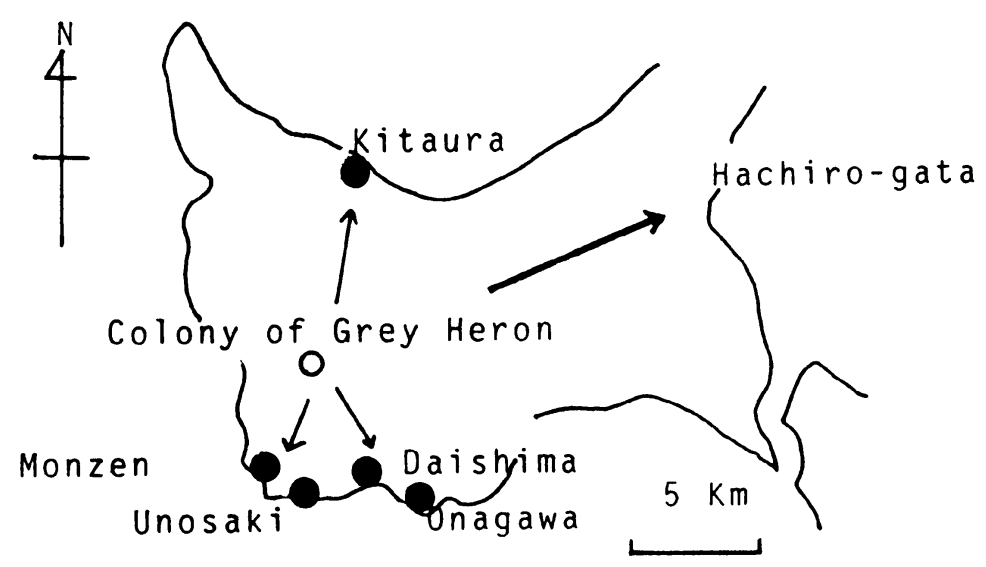

Fig. 8. The foraging routes from the colony to the foraging areas.

In later breeding period, the proportion of feeding parents increased at the peripheral part of the colony, and at type A and B nests. The chicks of lower site nests tended to fledge later. From these facts, it can be concluded that more peripheral or lower positioned nests were built later. This implies that the pairs which arrived earlier at breeding area occupy higher nesting sites in the center of breeding area, and later arrivals are forced to choose lower and relatively peripheral positions.

Fig. 8 shows the direction of foraging departure. Broad arrow along small valley is the most frequent flyway confirmed by all-day observation, especially in morning and evening. Between 12 and 18 o'clock, often in fine and hot days, some birds took other flyways beyound mountains shown by narrow arrows. These over mountain flyways were more often used to and from the south, rather than north-east.

According to Hashimoto \& Ogasawara (1968), Grey Herons flew further away to forage for nestlings. In this case, feeding area extended as far as Kitaura, Monzen to Hachiro-gata.

Observations of Grey Herons in feeding areas were made seven times at Kitaura, Unosaki, Daishima, Onagawa three times, and Hachiro-gata. In Hachiro-gata, several individuals were observed everytime (min. 3 and max. 8), but between Kitaura and Onagawa in Oga Peninsula, only two individuals were only once found at Unosaki. Most freqeunt route along valley coincided with the flyway from the colony to Hachriogata.

The sexual difference of Grey Herons is slight, and they always forage together. We observed parent birds return together to the nest and fed the chicks at the same time.

During early stage of breeding, parents pass the food inserting their own beak into the mouth of nestlings. In middle to late stage, parent vomits food and the nestlings accept them whole by themselves. Grown-up immature often urges parent to vomit food by biting beaks of parent, and after eating it similar biting is repeated. Chicks or a brood compete for parent's food with such a manner. After feeding the chicks, most of the parents take one or two minutes rest, and then leaves nest for next foraging. 
Table 8. Food items dropped under the colony of Grey Heron.

\begin{tabular}{|c|c|}
\hline Dates & Food items \\
\hline 20 June & Carassius gibeli (1) \\
\hline 11 July & $\begin{array}{l}\text { Microtus m. montebelli (1), Carassius auratus (1), } \\
\text { Three scales of Carassius auratus, Frog (1). }\end{array}$ \\
\hline 14 July & Zacco platypus (1) \\
\hline 17 July & Misgurnus anguillicaudatus (2) \\
\hline 25 July & Frog (2), Carassius auratus (1) \\
\hline 2 Aug. & Microtus m. montebelli (1), Misgurnus anguillicaudatus (1) \\
\hline 9 Aug. & Microtus m. montebelli (3), Frog (1) \\
\hline 21 Aug. & A big tail of Mugil cephalus \\
\hline 3 Sept. & Small fish (1), Geothelhusa dehaanii (1) \\
\hline 19 Aug. & $\begin{array}{l}\text { (Omonogawa-machi), Misgurnus anguillicaudatus (1), } \\
\text { Frog (4), Procambarus clarkii (many). }\end{array}$ \\
\hline
\end{tabular}

As Grey herons are nervous for observer, it is very difficult to identify food items at closer ranges. Their food menue can, however, be represented by fallen samples collected under the nest trees (Table 8). Fishes were mostly fresh water species and adults and larvae of frogs were common. All of the mice thus collected were Japanesemeadow Mice (Microtus montebelli montebelli). Large quantity of pellets could also be found under the nests. The contents were mostly hairs of mice (Microtus m. montebelli) (identified by Dr. H. Abe, Hokkaido University), and legs and feather of small birds were mixed in small quantity. According to collected samples and field observations, Hachirogata can be regarded as the principal feeding area of Grey Herons, as reported before by Hashimoto \& Ogasawara (1968).

\section{Mortality and decomposers}

Insect and mice traps were set on the ground under nest trees, five times during 5 August to 6 November, 1980. There was remakable difference in propotion and abundance of insect-species between the results obtained before 3 September, when the last Grey Heron left this colony for wintering, and the results of after that date. Percentage of Silphidae was about $50 \%$ before 3 September, but after that it decreased, and instead, Staphylinidae and Harpalidae increased to over $50 \%$.

In Silphidae, Nicrophorus quadripunctatus was the most common species which could easily be found also in surrounding planted cedar forest. Nicrophorus concolor is the largest sized species of this family in Japan. Species of Silphidae, except $N$. quadripanctatus, were found almost all before 3 September. These species eat-off body skin of dead Grey Heron with their strong mouth, and then ate the inside of it.

Two species of ants appeared especially numerously in early stage of decomposing of the body. When the body was well-decomposed, number of ants decreased. However, they were found even in November. Flies layed eggs on the body immediately when a chick dropped. During June and August, worms hatched out by the next day. After 4 days, inside of the body was filled with them. It took about only 8 days for worms to 
decompose the body completely, except feathers and bones. From middle of September, speed of decomposing by the worms apparently decreased.

Two species of small unidentifiable beetles, were always found especially numerously in later stage of decomposing. Ticks were found in large numbers; some of them were on bait, and others were parasitic $N$. quadripunctatus.

By mouse-traps, Old World Wood Mice (Apodemus speciosus speciosus) and Japanese Shrew Moles (Urotrichus talpoides hondonis) were captured.

Cases of bait loss were more common in 1st and 2nd trials. This seemed to be by small beetles or ants.

While Grey Herons were present in the forest, only the Wood Mouse was captured. After that, the Shrew Moles were captured for the first time on third trial, and at the same time capture of Wood Mice also somewhat increased. Competitive food relation between these two species, and cause of the change of their numbers remain to be further studied.

Some of mouse-traps were turned over or moved to several meters from the first positions. This suggested existance of other mammals larger than mice or moles, but could not be confirmed.

\section{Discussion and Conclusion}

Grey Herons have bred in the natural cedar forest long times, at least since WWII, or earlier. As the results, big old cedar trees have graduarely died year by year. Consequently the heron colony moved in the forest. The heron nested first at the top of tree, which part died first, and then branches under the nest graduarely died, and finally a whole tree died. But the dying speed of a tree by affection of herons could not be determined.

It was clear that dropped foods (fishes, frogs, mice, etc.) from nests and dead-

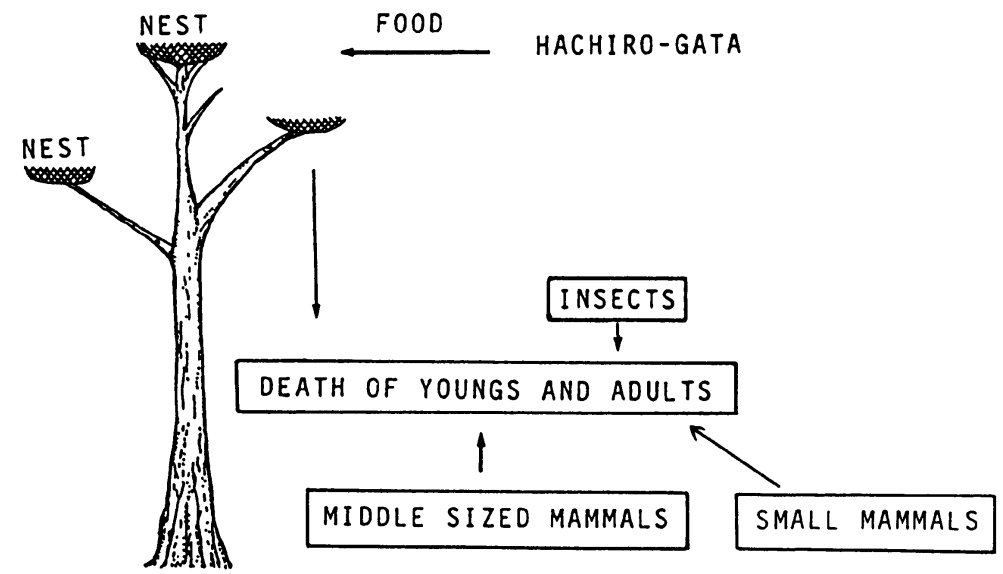

Fig. 9. Schematic relationships between the dead nestlings and adults, and their predators and decomposers. 
nestling and adult birds were eaten by mice and unknown middle-sized mammals, and decomposers of many insects. This relationship in this heron's colony is shown schematically in Fig. 9.

Population-size of this heron could be roughly estimated by number of nests and average brood-size, but more precise observations are desirable. Structure and abundance of decomposer community should also be surveyed. Cause of death of adult birds found dropped on the ground under nesting trees remains unknown. However, the time of their death coincided with that of the spray of agricultural medicines made by helicopter, especially on Hachirogata area.

\section{Acknowledgments}

We thank Mr. M. Kohmaru, Mr. M. Ogawa, Mr. I. Sato, Mr. S. Noro, and Mr. T. Shugibuchi who helped our field survey. We also thank Dr. H. Abe, Hokkaido University who identified the species from hairs of mice contained in many pellets of Grey Heron, and Dr. N. Kuroda who read the English draft of the manuscript.

\section{References}

Ogawa, M. 1979. On the breeding ecology of Grey Heron on Mt. Honzan of Oga Peninsula. Report of Saitoh Kenzo-Kensho-Kai. (Manuscript in Japanese).

Hashimoto, K. \& Ogasawara, K. 1968. A colony of Grey Heron on Mt. Honzan of Oga Peninsula. Nature of Tohoku 13: 7-8. (in Japanese).

Watanabe, H. 1976. Heron colonies found in Yukyuzan park. Bulletin of the Nagoka Municipal Science Museum. No. 12; 47-60. (in Japanese). 